\title{
Predicting manufacturing employee turnover intentions
}

Employee

turnover intentions

\author{
Angie R. Skelton \\ Blue Mountain College, Blue Mountain, Mississippi, USA, and \\ Deborah Nattress and Rocky J. Dwyer \\ College of Management and Technology, Walden University, \\ Minneapolis, Minnesota, USA
}

\begin{abstract}
Purpose - Employee turnover expenses can cost businesses more than 100 per cent of a single employee's annual wages and negatively affection an organization's production and profits. High employee turnover also could affect community tax collections, social programs and physical and mental health issues. Therefore, understanding contributors to higher employee turnover remains essential for organizational managers from both a corporate and societal standpoint. This paper aims to provide an analysis of how job satisfaction and job embeddedness could predict employee turnover intent.

Design/methodology/approach - A randomly selected survey which consisted of Andrews and Withey's (1976) job satisfaction questionnaire, a global job embeddedness scale (Crossley et al., 2007) and a three-item turnover intent questionnaire derived from a survey created by Mobley et al. (1978) using a Likerttype measurement to survey randomly selected individuals used within manufacturing plants located in the Southeastern USA.

Findings - The results of the multiple regression analysis showed a significant relationship between job satisfaction, job embeddedness and turnover intent; and that satisfied and committed employees are less likely to plan to leave their employment.

Originality/value - Limited current information is available on how job satisfaction and job embeddedness predict turnover intentions in US Southeast manufacturing. This study includes information that shows the importance of job satisfaction and job embeddedness on retaining employees in this region and industry. Given the importance of employee retention on corporate productivity, morale and profits along with the ability to improve the organization's positive contribution to society, it is important for managers to understand these factors and their effect on employee turnover intent.
\end{abstract}

Keywords Manufacturing, Job satisfaction, Job embeddedness, Employee retention, Employee turnover intentions

Paper type Research paper

\section{Introduction}

A significant correlation exists between the financial performance of manufacturers and employee turnover, making employee turnover intent a substantial area of study within the manufacturing industry (Hancock et al., 2013). Employee turnover is important to address because high attrition can extensively affect companies, directly and indirectly, resulting in

(C) Angie R. Skelton, Deborah Nattress and Rocky J. Dwyer. Published in Journal of Economics, Finance and Administrative Science. Published by Emerald Publishing Limited. This article is published under the Creative Commons Attribution (CC BY 4.0) licence. Anyone may reproduce, distribute, translate and create derivative works of this article (for both commercial and noncommercial purposes), subject to full attribution to the original publication and authors. The full terms of this licence may be seen at: http://creativecommons.org/licences/by/4.0/legalcode
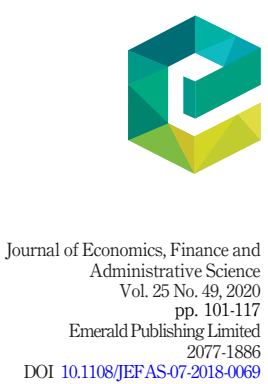
JEFAS

25,49

102 increased hiring and training costs, lost production, reduced profits and overall lower employee morale (Hayward et al., 2016). Studying employee turnover in manufacturing is critical as more than 12 million individuals work in the industry, making up approximately 8.8 per cent of the US economy. A significant portion of the manufacturing employees works in the Southeast, where manufacturing organizational leaders employ 19 per cent of the industry's workforce (Scott, 2015; the USA Environmental Protection Agency, 2016). As Vasquez (2014) stated, a ripple effect from employee turnover could ultimately lead to a global economic slowdown, which can impact all of society. Therefore, this study could prove significant to both organizations and society.

The specific problem addressed through this study was that some manufacturing managers in the Southeastern USA do not understand the extent to which employee job satisfaction and job embeddedness predict employee turnover intentions. While individual scholars have addressed the problem of employee turnover intent, recent researchers have focused on areas outside of the USA and in industries other than manufacturing ( $\mathrm{Lu}$ and Gursoy, 2016). As limited current research encompassing Southeastern US manufacturing employee turnover exists, this study remains timely.

\section{Previous research on turnover intent, job satisfaction and job embeddedness}

When Herzberg et al. (1959) introduced the motivation-hygiene theory, they suggested that once basic hygiene needs occur for workers, they search for job satisfaction. What Herzberg et al. considered hygiene needs included the basics of salary, safe work conditions and relationships with peers, subordinates and supervisors (Denton and Maatgi, 2016). What these scholars discovered, once these basic employment needs occurred, is that motivation should occur through genuine job satisfaction, or employees become more likely to experience discontentment and dissatisfaction (Denton and Maatgi, 2016). Ali (2016) reiterated Herzberg's thoughts and stated that hygiene factors help prevent dissatisfaction, but motivational factors help keep employees satisfied. Some of the current factors that can contribute to job satisfaction include achievement, personal and professional development, job growth, the feeling of fulfillment in the job performed, personal achievement and recognition (Belias and Koustelios, 2014; Denton and Maatgi, 2016).

Belias and Koustelios (2014) noted the significance of Herzberg's work included the global use of both intrinsic and extrinsic motivational factors affecting job satisfaction. Therefore, these researchers noted that managers might use Herzberg's theory to understand how to improve job satisfaction and weaken factors that might influence job dissatisfaction. Other scholars noted that Herzberg believed during times when employees lacked motivation, their intent to leave increased as they began to perform job searches and plan their exit strategy from the current employer (Derby-Davis, 2014).

Denton and Maatgi (2016) used the concepts developed by Herzberg et al. (1959) in their recommendations for creating employee support for the implementation of ISP 9000 standards within small and medium-sized advanced engineering and manufacturing enterprises. These scholars suggested that internal motivation could improve employee results substantially over external pressure (Denton and Maatgi, 2016). Additionally, Denton and Maatgi noted that management, administrative leadership and the work environment impact success in any manufacturing facility, which reflects the importance of the strategies that managers use to enhance job satisfaction, not only for organizational profits but also for employee retention.

Researchers also noted embeddedness to both the organization of employment and the community in which the employee lives remain significant predictors of intent to stay (Nicholas et al., 2016). However, employers can only influence the organizational aspects of a 
worker's embeddedness (Choi and Kim, 2015). Kanten et al. (2015) stated the characteristics of a learning organization affect employee performance and job embeddedness levels. Therefore, organizations might concentrate on increasing offering opportunities for employee training and development. Job embeddedness remains beneficial, not only to the organization due to better quality output and reduced turnover but also benefits the employee through higher individual performance (Kanten et al., 2015). Consequently, because of the significant mutual benefit, job embeddedness is also an important characteristic for managers to address.

\section{Turnover intent}

Turnover intent is the probability that an employee will leave an organization (Mobley et al., 1978). Researchers measure turnover intent using specific time intervals, and they regard it as a choice concerning an individual leaving a current employer (Wong et al., 2015). Researchers suggested that positive turnover intentions remain correlated to actual voluntary turnover (Hancock et al., 2013), which makes this topic an important one for an organization's managers to consider and to prevent since high turnover negatively affects businesses (Hayward et al., 2016). Scholars noted several factors that might contribute to an individual's increased consideration leaving an organization, including job satisfaction ( $\mathrm{Yu}$ and Kang, 2016) and job embeddedness (Ko and Kim, 2016).

Lu and Gursoy (2016) suggested generational differences also might cause differences in how employees value their jobs and variations of worker burnout, leading to higher turnover intent. These researchers noted three generational groups dominating the current workforce: baby boomers, Generation X and millennials. Rani and Samuel (2016) suggested when managers understand generational differences in the workforce, they can implement better policies that meet the needs of each generation. As the baby boomer generation controls many organizations, scholars suggested a mismatch could occur between the values of managers and millennial workers (Rani and Samuel, 2016). Additionally, Lyons and Kuron (2014) noted that understanding millennials' needs and differences in the workforce improves their productivity and innovation, which often strengthens job satisfaction and decreases turnover intent.

\section{Job satisfaction}

Job satisfaction remains relevant to organizations. Scholars noted that job satisfaction remains central to successful human resource management (Hauff et al., 2015). Additionally, researchers suggested that job satisfaction remains complex due to cultural variances in a globalized economy and due to differences in individual needs and jobs (Hauff et al., 2015; Pan, 2015). Ali (2016) noted the importance of job satisfaction among employees in organizations, stating that people remain a core asset to any business as they are the ones who ensure production occurs. This researcher also indicated executives and managers should make and enforce policies that will enhance employee satisfaction to avoid negative consequences from dissatisfaction, including organizational performance, lower productivity and employee turnover (Ali, 2016). Huang and Su (2016) suggested that one symptom of an employee's intent to leave a company might include low job satisfaction. Therefore, because of the importance of job satisfaction, managers should work toward increasing employee satisfaction to help improve efficiency, production and employee retention.

Job satisfaction remains a complex topic due to national and cultural differences and the various components it encompasses and affects. Pan (2015), for instance, noted job satisfaction remains subjective and person-specific. Therefore, what creates satisfaction for
Employee turnover intentions 
JEFAS

25,49

104

one employee might not meet the needs of another employee. Additionally, Pan suggested job satisfaction includes task, environmental and relational factors. As an example of the importance of work relationships, De Beer et al. (2016) suggested increasing the quality of relationship exchanges between the supervisor and the employee to help strengthen job satisfaction and improve work engagement, which could contribute positively to both the employee and the organization.

The contributions to job satisfaction and the results of employees liking their jobs remain broad. Umamaheswari and Krishnan (2015) suggested employee satisfaction could contribute to increased organizational commitment, reduced intent to quit, and ultimately increased retention rates. Various issues contribute to each of these factors. However, the relationships between each of these factors remain significant.

Ali (2016) also noted that employee motivation and job satisfaction remain different, yet they are related. As Ali suggested, job design, including the empowerment of employees through organizational policies, could help improve satisfaction. Motivation, however, remains more of an individual or intrinsic trait that cannot necessarily occur through corporate strategies or policies (Ali, 2016). Managers can improve strategies to help strengthen employee job satisfaction and better motivate workers (De Beer et al., 2016; Huang and Su, 2016; Pan, 2015).

\section{Job embeddedness}

Scholars have noted that job embeddedness might indirectly help increase retention and reduce organizational turnover costs (Marasi et al., 2016). To help researchers study job embeddedness, Nicholas et al. (2016) suggested three kinds of attachments or dimensions that might entice an individual to remain in an organization or community: fits, links and sacrifice. Various researchers used these dimensions in their research (Chhabra, 2015; Schmitt et al., 2015; Word and Park, 2015).

Word and Park (2015) noted that organizational and personal job fit remain essential to a company's success. These scholars defined person-job fit as when the individual is right and suitable for the job based on personal values and abilities (Word and Park, 2015). Chhabra (2015) suggested that personal job fit enhances a worker's socialization, satisfaction and commitment in a job. Additionally, the scholar noted that personal job fit decreases discontentment and intent to leave an organization (Chhabra, 2015). Likewise, Schmitt et al. (2015) stated employees with a higher perceived fit between the demands of their job and their skill and abilities experience less exhaustion than employees with abilities misfit to the job.

Person-organization fit also remains relevant to a company. Word and Park (2015) defined person-organization fit as the congruence between the employee's values and the mission of the organization for which he or she works. Anaza (2015) noted that personorganization fit positively correlates with employee-customer identification, as employees feel pride when they identify with their company and they, therefore, remain dedicated to their job and the organization. Other scholars noted organizations might use personorganization fit as an instrument in reaching their targets, suggesting employees who fit best within a company have stronger job satisfaction and lower turnover intent than workers with a lower person-organization fit (Findik et al., 2013).

Two other dimensions important to job embeddedness include links and sacrifice. Karatepe (2016) suggested job embeddedness strengthens as an employee's links to the organization, co-workers and the job increase. This scholar also noted that stronger co-worker and family support while in a job decreases the chance of sacrificing quality relationships the employee has (Karatepe, 2016). 
In addition, Charlier et al. (2016) suggested that job embeddedness helps explain why employees fit into their job, organization and community, as well as the type of sacrifice that must occur to break the fit link and move to another job possibly in a different organization or city. Likewise, other scholars noted a strong organization fit, which includes the compatibility of an individual to specific job settings and the work culture and environment, helps strengthen the employee's ties to a company (Nicholas et al., 2016). While researchers noted that job embeddedness could contain some negative organizational outcomes in certain circumstances, some suggested it remains positively associated with employee retention (Charlier et al., 2016). Therefore, it was a consideration in this study.

\section{Conceptually}

For this study, the two-factor theory from Herzberg et al. (1959) and the job embeddedness theory from Mitchell et al. (2001) provided the rationales for examining the extent to which employee job satisfaction and job embeddedness predict employee turnover intentions. According to Herzberg's theory, job satisfaction should predict employee turnover intentions. Likewise, according to Mitchell et al., job embeddedness should predict employee turnover intentions.

\section{Survey instruments}

The survey instruments for this study consisted of:

- Andrews and Withey's (1976) job satisfaction questionnaire;

- A global job embeddedness scale (Crossley et al., 2007); and

- A three-item turnover intent questionnaire derived from a survey created by Mobley et al. (1978).

All three surveys instruments include rating scales using a Likert-type measurement. Even though the Likert-type rating scales might not represent equal intervals, scholars noted rating scale data are closer to interval data than ordinal data (Meyers et al., 2013). Therefore, this research includes interval data used for statistical analyses. Researchers collected data from participants by combining these instruments into one single survey accessible through SurveyMonkey ${ }^{\circledR}$ Audience online.

Andrews and Withey's (1976) job satisfaction questionnaire measures the satisfaction level of employees using a seven-point Likert-type scale $(1=$ terrible; $2=$ unhappy; $3=$ mostly dissatisfied; $4=$ mixed; $5=$ mostly satisfied; $6=$ pleased; $7=$ delighted). This instrument contains five questions, encompassing how the employee feels about co-workers, the job overall, work environment, specific work performed, available equipment, information and human resources for job performance. Using an interval scale, the higher the employee results for these questions, the stronger the job satisfaction level.

The measurement of job embeddedness occurred through the use of Crossley et al.'s (2007) global job embeddedness scale. This scale measures job embeddedness using a fivepoint Likert-type scale $(1=$ strongly disagree; $2=$ disagree; $3=$ neutral; $4=$ agree; $5=$ strongly agree). This instrument contains six questions from the global job embeddedness scale encompassing how attached the employee is to the organization. All questions from the original survey appeared in this measurement except one, which stated, It would be easy for me to leave this organization. This question did not appear in the survey for this study because another question already measures this information. Using an interval scale, the higher the results collected, the more embedded the employee is in the organization. Various 
JEFAS

25,49

106

scholars used this instrument in their studies to measure employee job embeddedness (Chen and Wen, 2016; Karatepe, 2016).

The last measurement used includes three questions from Mobley et al.'s (1978) survey on intent to stay. This scale measures intent to stay using a five-point Likert-type scale $(1=$ strongly disagree; $2=$ disagree; $3=$ neutral; $4=$ agree; $5=$ strongly agree). The three questions included in this section of the questionnaire include:

(1) I often think of leaving the organization.

(2) I intend to look for a new job within the next year.

(3) If I could choose again, I would not work for this organization.

Using an interval scale, the higher the added score for this section of the survey, the more likely the individual was to hold the intent to leave the organization.

\section{Reliability of the survey instruments}

Researchers use generalizability of the results to show the external validity of an instrument (Lancsar and Swait, 2014). Limits exist for the generalization of this study based on the industry and region it encompasses. However, scholars used the instruments that encompass the study and noted their validity (Chen and Wen, 2016).

Cronbach's alpha is a popular and reliable internal consistency measurement used in the social and organizational sciences (Bonett and Wright, 2014). Scholars noted a score of 0.80 and above is considered an acceptable level of reliability for Cronbach's alpha (Lonial and Carter, 2015). Therefore, for this study, concluding levels of 0.80 and higher show increased reliability.

For each of the instruments used for this study, scholars previously showed their validity and reliability. Umans et al. (2016) demonstrated the Andrews and Withey's (1976) job satisfaction scale had a reliability of 0.83 , which reflects internal consistency, as the value remains above 0.80 . Additionally, scholars noted the Andrews and Withey job satisfaction scale remains significantly correlated at 0.70 with the job descriptive index and the Minnesota Satisfaction Questionnaire, two reliable instruments used to measure job satisfaction (Hurt et al., 2013).

Scholars also noted the validity and reliability for the Crossley et al. (2007) job embeddedness scale. Karatepe (2016) demonstrated the reliability of this job embeddedness scale through research conducted in the hospitality industry. Other scholars tested the reliability and validity of the Crossley et al. job embeddedness scale and concluded an average variance extracted (AVE) construct validity of 71.06 per cent and reliability of 0.94 (Marasi et al., 2016). Therefore, based on these scholars' tests, the Crossley et al. job embeddedness scale shows both validity and reliability.

Scholars also confirmed the validity and reliability of the three-item questionnaire by Mobley et al. (1978) for turnover intent. Salman et al. (2016) showed the reliability of 0.91 for this turnover intent instrument using Cronbach's alpha. Other scholars confirmed the validity of Mobley et al.'s instrument by showing its correlation with actual employee turnover one year after participants completed the survey (Chen et al., 2014). Additionally, these scholars confirmed the reliability of the instrument using Cronbach's alpha, which was 0.84 in their study.

\section{Data analysis}

Using SPSS, a model fit diagnostic for multiple linear regression showed the predictor and criterion variables of this study. Based on the information from Table I, the $R^{2}$ value was 
0.705 , while the adjusted $R^{2}$ value was .696 . These values indicate that the regression line explains approximately 70 per cent of the variability of the response data to the mean. The amount of variance explained was 0.705 , indicating the independent variables in the model explain approximately 70 per cent of the variance in the dependent variable.

Employee turnover intentions

\section{Descriptive statistics}

Based on output results from $\mathrm{G}$ *Power 3.1.9.2, the minimum sample size for this study was 37 to 50 participants. These results were concluded using an a priori size evaluation for a two-tailed, linear regression random model. To prevent a Type II error, the desire was to collect between 60 and 100 qualified surveys from participants randomly selected using SurveyMonkey ${ }^{\circledR}$ Audience members. SurveyMonkey ${ }^{\circledR}$ Audience only guaranteed the receipt of 75 results. While the final study results included 81 surveys, with the omission of incomplete surveys and outliers, only 63 participant surveys remained. This number exceeded the required number of surveys needed to prevent Type II errors, even though it was a smaller number than originally desired.

The descriptive statistics for this study, located in Table II, show the mean for turnover intent was 2.370 with a $S D$ of 1.069 . For job satisfaction, the mean was 3.781 with a SD of 0.650. For job embeddedness, the mean was 3.177 with a SD of 1.07. The performance of bootstrapping on these statistics showed the results within a 95 per cent confidence interval based on 1,000 bootstrap samples.

\begin{tabular}{ccccc}
\hline Model $^{\mathrm{a}}$ & $R$ & $R$-square & Adjusted $R$-square & Std. error of the estimate \\
\hline 1 & $0.840^{\mathrm{a}}$ & 0.705 & 0.696 & 0.59010
\end{tabular}

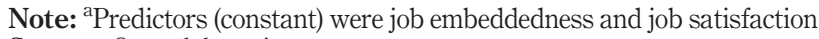

Table I.

Source: Own elaboration

Model summary

\begin{tabular}{|c|c|c|c|c|c|}
\hline \multirow[b]{3}{*}{ Measure } & \multirow[b]{3}{*}{ Statistic } & \multicolumn{4}{|c|}{ Bootstrap $^{a}$} \\
\hline & & & & $95 \%$ cor & erval \\
\hline & & Bias & Std. error & Lower & Upper \\
\hline \multicolumn{6}{|c|}{ Turnover intent } \\
\hline$M$ & 2.3704 & -0.0025 & 0.1332 & 2.1164 & 2.6349 \\
\hline$S D$ & 1.06947 & -0.01327 & 0.08112 & 0.89570 & 1.20928 \\
\hline$N$ & 63 & 0 & 0 & 63 & 63 \\
\hline \multicolumn{6}{|c|}{ Job satisfaction } \\
\hline$M$ & 3.7810 & 0.0018 & 0.0811 & 3.6254 & 3.9365 \\
\hline$S D$ & 0.65027 & -0.00868 & 0.05902 & 0.52452 & 0.75831 \\
\hline$N$ & 63 & 0 & 0 & 63 & 63 \\
\hline \multicolumn{6}{|c|}{ Job embeddedness } \\
\hline$M$ & 3.1772 & -0.0010 & 0.1332 & 2.9180 & 3.4259 \\
\hline$S D$ & 1.07341 & -0.01306 & 0.07668 & 0.90811 & 1.20977 \\
\hline$N$ & 63 & 0 & 0 & 63 & 63 \\
\hline
\end{tabular}

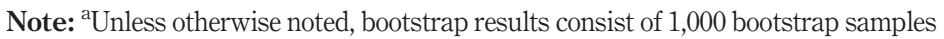

Table II.

Source: Own elaboration

Descriptive statistics 
JEFAS

25,49

108

Table III includes the frequencies specifically for the criterion variable. The data included in this table show the frequency of the various responses to all 63 surveys used for this study. The frequency results correspond to the Likert scale results of 1 (strongly disagree) to 5 (strongly agree) using the Mobley et al. (1978) intent to stay questionnaire.

\section{Inferential statistics}

The primary research question that guided this study was:

RQ1. To what extent do a linear combination of employee job satisfaction and job embeddedness predict employee turnover intentions in the manufacturing industry in the Southeastern USA?

Multiple linear regression analysis was performed where alpha was predetermined at 0.05 (two-tailed) to examine how well job satisfaction and job embeddedness predict employee turnover intentions. For this study, the significance level was $<0.001$, which is less than 0.05 . Because the significant level, or $p$-value, was less than 0.05 , the acceptance of the alternative hypothesis had to occur. The alternative hypothesis was as follows: A linear combination of employee job satisfaction and job embeddedness is a significant predictor of employee turnover intentions in the manufacturing industry in the Southeastern USA. There were two degrees of freedom for this study, as shown in Table IV.

Through analysis of the covariance numbers in Table $\mathrm{V}$, the negative relationship was confirmed between the two predictor variables and turnover intent $(-0.703$ and -0.501$)$. The results of this analysis indicated the null hypothesis should be rejected. The null hypothesis was as follows: A linear combination of employee job satisfaction and job embeddedness is not a predictor of employee turnover intentions in the manufacturing industry in the Southeastern USA. Likewise, the alternative hypothesis was accepted. The alternative hypothesis was as follows: A linear combination of employee job satisfaction and job embeddedness is a significant predictor of employee turnover intentions in the manufacturing industry in the Southeastern USA.

\begin{tabular}{|c|c|c|c|c|c|c|c|c|}
\hline \multirow{2}{*}{$\begin{array}{l}\text { Likert scale } \\
\text { response }\end{array}$} & \multirow[b]{2}{*}{$f$} & \multirow[b]{2}{*}{$(\%)$} & \multirow[b]{2}{*}{ Valid (\%) } & \multirow[b]{2}{*}{ Cumulative (\%) } & \multicolumn{4}{|c|}{$\begin{array}{c}\text { Bootstrap for percent }{ }^{\mathrm{a}} \\
95 \% \\
\text { confidence } \\
\text { interval }\end{array}$} \\
\hline & & & & & Bias & $S E$ & Lower & Upper \\
\hline 1.00 & 12 & 19.0 & 19.0 & 19.0 & -0.2 & 5.0 & 9.5 & 28.6 \\
\hline 1.33 & 5 & 7.9 & 7.9 & 27.0 & 0.0 & 3.4 & 1.6 & 15.9 \\
\hline 1.67 & 3 & 4.8 & 4.8 & 31.7 & -0.1 & 2.6 & 0.0 & 9.5 \\
\hline 2.00 & 11 & 17.5 & 17.5 & 49.2 & 0.3 & 4.8 & 9.5 & 27.0 \\
\hline 2.33 & 5 & 7.9 & 7.9 & 57.1 & 0.0 & 3.3 & 1.6 & 14.3 \\
\hline 2.67 & 6 & 9.5 & 9.5 & 66.7 & 0.0 & 3.7 & 3.2 & 17.5 \\
\hline 3.00 & 5 & 7.9 & 7.9 & 74.6 & 0.1 & 3.4 & 1.6 & 14.3 \\
\hline 3.33 & 5 & 7.9 & 7.9 & 82.5 & 0.1 & 3.4 & 1.6 & 14.3 \\
\hline 3.67 & 5 & 7.9 & 7.9 & 90.5 & -0.2 & 3.3 & 1.6 & 14.3 \\
\hline 4.00 & 4 & 6.3 & 6.3 & 96.8 & -0.2 & 3.1 & 1.6 & 12.7 \\
\hline 5.00 & 2 & 3.2 & 3.2 & 100.0 & 0.0 & 2.1 & 0.0 & 7.9 \\
\hline Total & 63 & 100.0 & 100.0 & & 0.0 & 0.0 & 100.0 & 100.0 \\
\hline
\end{tabular}

Note: ${ }^{a}$ Unless otherwise noted, bootstrap results consist of 1,000 bootstrap samples Source: Own elaboration 
This study also included multivariate data. For this study, scatterplots were created in SPSS and reviewed. All participant results were omitted that fell outside of a 95 per cent confidence interval as noted by SPSS on the initial scatterplots. There were two outliers on the job satisfaction scatterplot and one on the job embeddedness scatterplot. Figures 1 and 2 include the final scatterplots for both job satisfaction and job embeddedness. These two figures exclude the outliers.

Another assumption made in this study was a normal distribution. While scholars noted that testing for normality is less important on large sample sizes (Field, 2013), it remained essential for this study due to the small number of survey participants. It is through normal distribution that researchers can gain confidence that the assumptions used in the study are valid. Based on scholars' suggestions (Field, 2013), both histograms and normal probability plots were used to test for normality. Based on Figures 3 through 7, these data were normally distributed. In Figures 3 and 4, one can see a normal bell curve for both job satisfaction data and job embeddedness results. In Figures 5 through 7, the data remain

\begin{tabular}{lccccc}
\hline Model & Sum of squares & df & Mean square & F & Sig. \\
\hline 1 & & & & & \\
Regression & 50.020 & 2 & 25.010 & 71.822 & $0.000^{\text {b }}$ \\
Residual & 20.893 & 60 & 0.348 & & \\
Total & 70.914 & 62 & & &
\end{tabular}

Note: ${ }^{a}$ Dependent variable was turnover intent; ${ }^{b}$ predictors (constant) were job embeddedness and job satisfaction

Source: Own elaboration

Table IV. ANOVA $^{\mathrm{a}}$

\begin{tabular}{|c|c|c|c|}
\hline Measure & Job satisfaction & Job embeddedness & Turnover intent \\
\hline \multicolumn{4}{|l|}{ Job satisfaction } \\
\hline Pearson correlation & 1 & $0.486 * *$ & $-0.703^{* *}$ \\
\hline Sig. (2-tailed) & & 0.000 & 0.000 \\
\hline Sum of squares and Cross-products & 27.298 & 22.866 & -32.882 \\
\hline Covariance & 0.420 & 0.352 & -0.506 \\
\hline$N$ & 66 & 66 & 66 \\
\hline \multicolumn{4}{|l|}{ Job embeddedness } \\
\hline Pearson correlation & $0.486^{* *}$ & 1 & $-0.501^{* *}$ \\
\hline Sig. (2-tailed) & 0.000 & & 0.000 \\
\hline Sum of squares and Cross-products & 22.866 & 81.236 & -40.409 \\
\hline Covariance & 0.352 & 1.250 & -0.622 \\
\hline$N$ & 66 & 66 & 66 \\
\hline \multicolumn{4}{|l|}{ Turnover intent } \\
\hline Pearson correlation & $-0.703^{* *}$ & $-0.501 * *$ & 1 \\
\hline Sig. (2-tailed) & 0.000 & 0.000 & \\
\hline Sum of squares and Cross-products & -32.882 & -40.409 & 80.197 \\
\hline Covariance & -0.506 & -0.622 & 1.234 \\
\hline$N$ & 66 & 66 & 66 \\
\hline
\end{tabular}

Note: $* *$ Correlation is significant at the 0.01 level (2-tailed)

Table V.

Source: Own elaboration 
JEFAS

25,49

110

Figure 1.

Scatterplot of job satisfaction and turnover intent

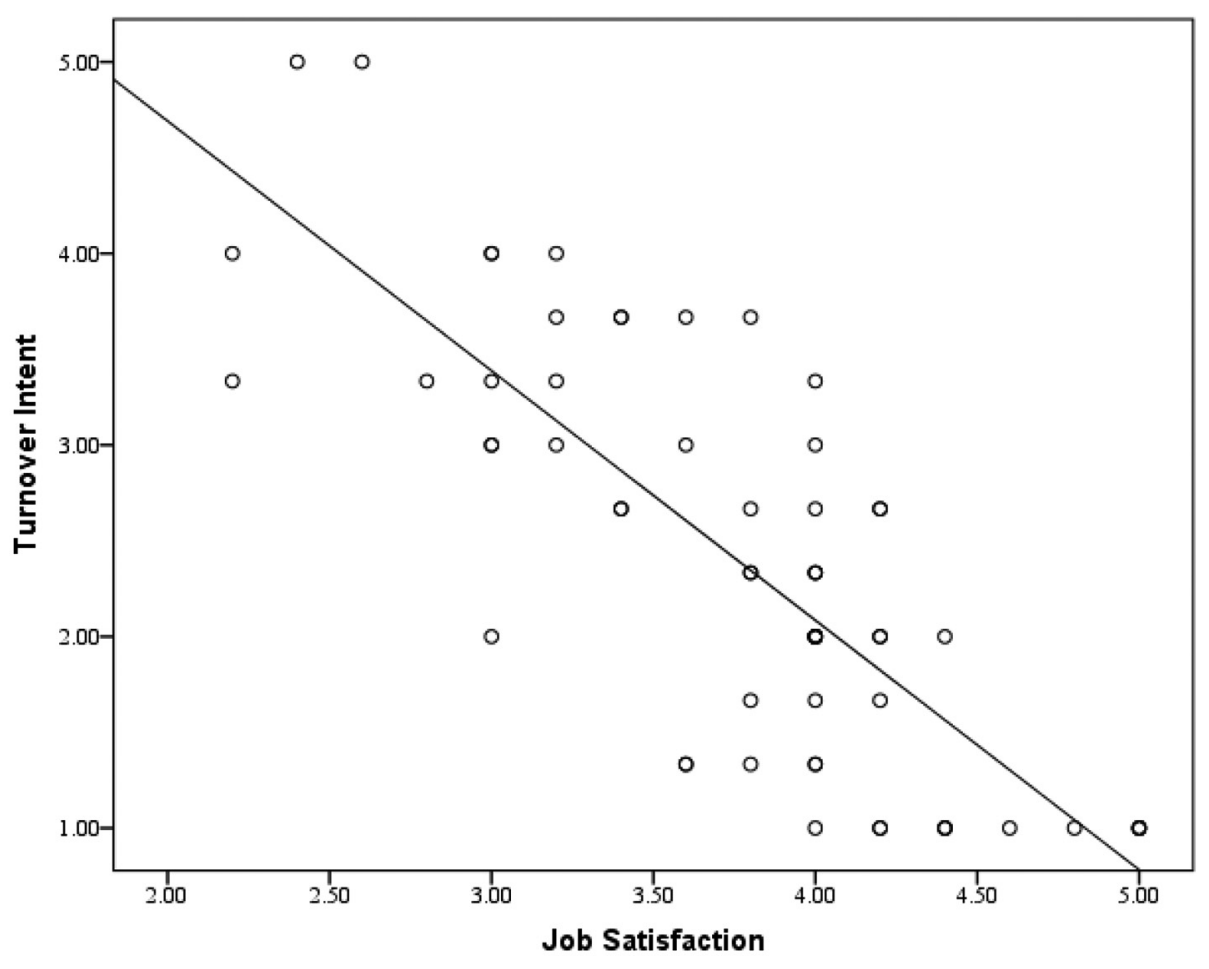

Source: Own elaboration

close to the 45-degree line, which researchers expect when viewing normal distributions. Therefore, based on the results from each of these figures, normal distribution occurred in this study (Figures 6 and 7).

The last assumption made in this study was that of linearity. When performing studies using multiple linear regression analysis, showing linearity in the results is important. Linearity occurs when the predictor and criterion variables align closely. Scholars noted that testing for linearity could occur through scatterplots (Field, 2013). Therefore, scatterplots were created and used in this study to prove linearity between the variables. The scatterplots for job satisfaction, job embeddedness and turnover intent appear in Figures 1 and 2 of this study. SPSS was used to create these figures, and the lines drawn in both graphs show the results of the predictor variables and the criterion variable. Based on these figures, linearity occurred in this study.

\section{Conclusions and research implications}

Hancock et al. (2013) suggested a significant correlation exists between the financial performance of manufacturers and employee turnover, which makes turnover intent an important area of study for the manufacturing industry. Upadhayay and Vrat (2016) noted total employee turnover expenses could cost businesses more than 100 per cent of a single employee's annual wages or salary, depending on the job left unoccupied. These scholars noted employee turnover decreases profits due to increased hiring costs and weaker 


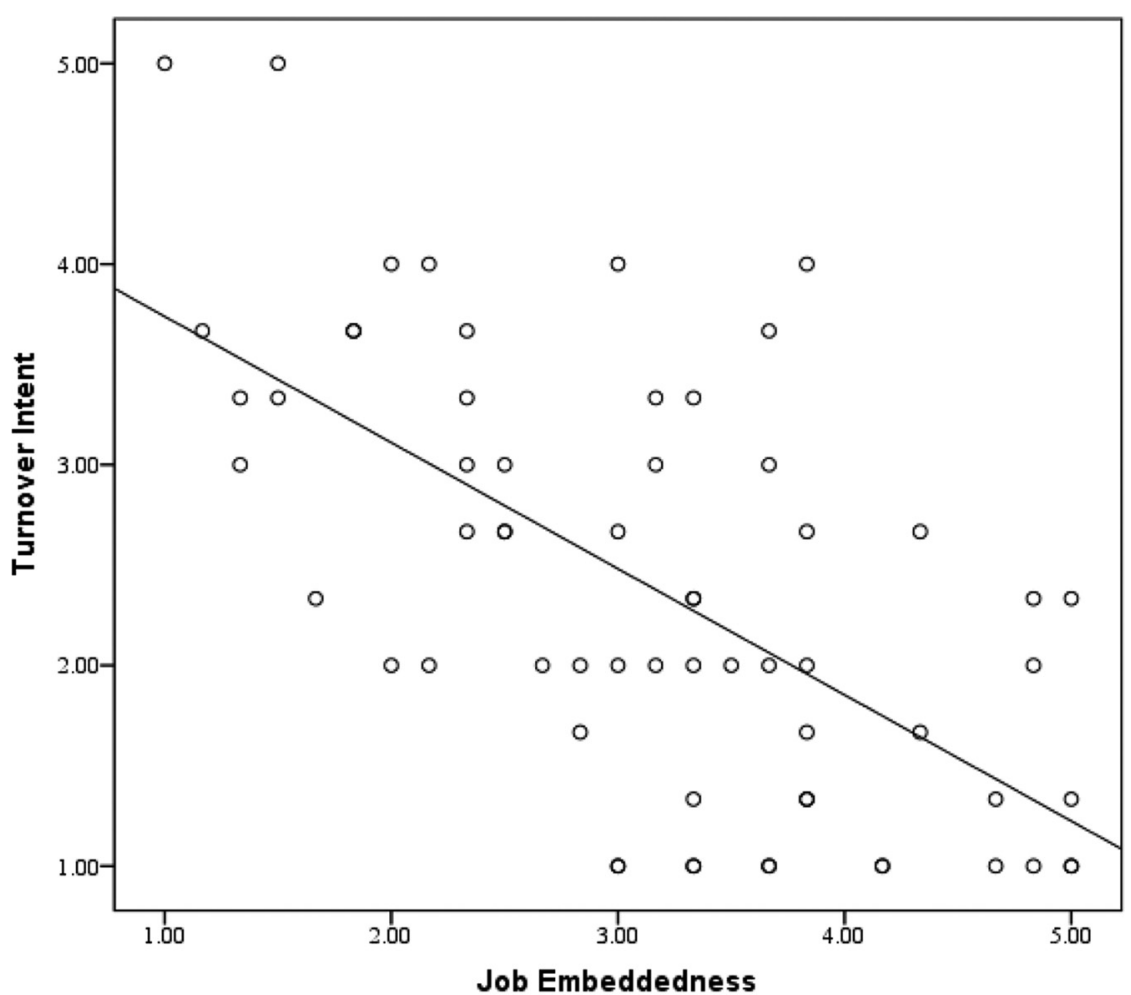

Source: Own elaboration
Employee turnover intentions

111

Figure 2.

Scatterplot of job embeddedness and turnover intent

employee performances (Upadhayay and Vrat, 2016). Therefore, understanding the variables that might contribute to turnover intent remains important. Additionally, the results of this study show that two predictor variables of turnover intent are job satisfaction and job embeddedness, making these two factors important for managers to consider when creating policies and procedures for employees.

\section{Managerial implications}

The results of this study reflect that a statistically significant correlation exists between job satisfaction, job embeddedness, and turnover intent among US Southeast manufacturing employees. If managers understand this relationship between job satisfaction and job embeddedness, they can begin concentrating their efforts on creating work environments that satisfy worker needs and embed employees to the organization and their specific jobs. However, once managers realize the correlation between these variables and decide to increase job satisfaction and job embeddedness within the workforce, they should begin to develop specific strategies that will align with their employees' needs and help better embed employees in the organization and to the job while improving their job satisfaction levels. Scholars noted that job satisfaction factors do not remain constant (O'Keefe et al., 2015). Likewise, each employee is different and what embeds one in a job might not similarly affect another. However, to help strengthen the production, sales and ending profits for an 
JEFAS

25,49

112

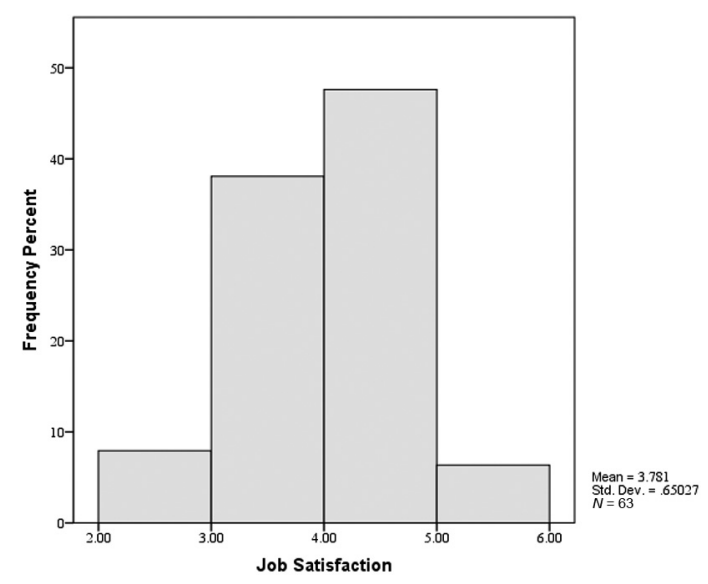

Figure 3.

Histogram of job

satisfaction

Source: Own elaboration

Figure 4.

Histogram for job embeddedness

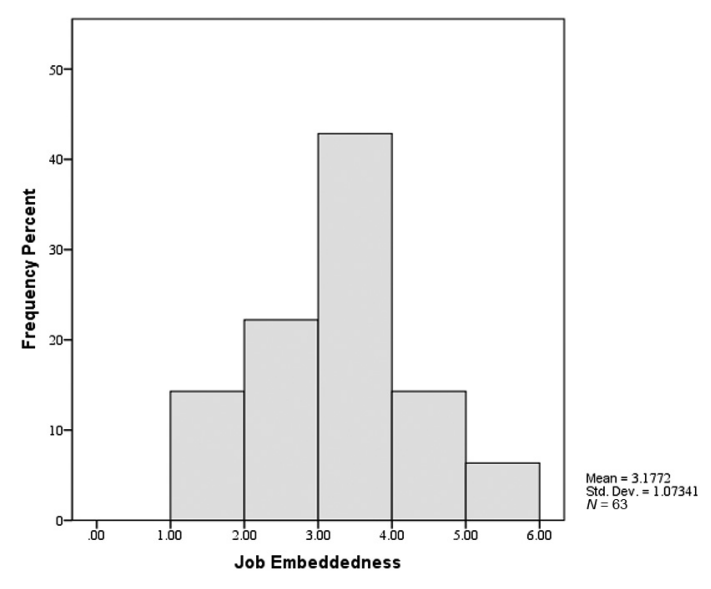

Source: Own elaboration

organization, it remains important to consider how to create job satisfaction and embeddedness to improve turnover intent. Additionally, based on the results of this study, it is important managers understand both job satisfaction and job embeddedness can help improve turnover intent in US Southeast manufacturing.

\section{Social change implications}

The results of this study not only affect individual organizations but also could impact local economies and society as well. Approximately 8.8 per cent of the US economy comes from the manufacturing industry. Additionally, US Southeast manufacturers employ 19 per cent 


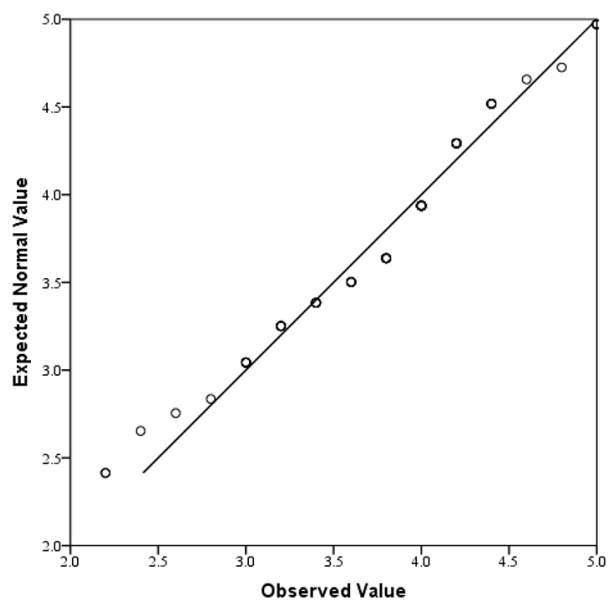

Source: Own elaboration

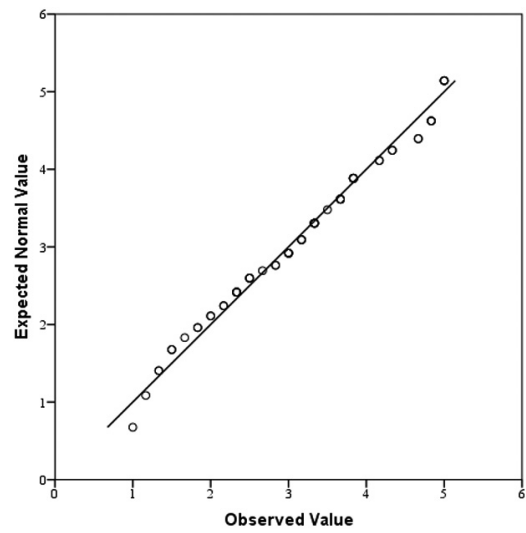

Source: Own elaboration
Employee

turnover

intentions

113

Figure 5.

Normal Q-Q plot of job satisfaction
Figure 6.

Normal Q-Q plot of job embeddedness

of the nation's manufacturing employees (Scott, 2015; the USA Environmental Protection Agency, 2016). Therefore, if weakness resides in this industry and region, other areas of the country might feel the effects as well. As Vasquez (2014) noted, significant turnover in organizations leads to slower economic growth as the unemployment rate increases in communities, which could influence tax collections and social programs.

Other more indirect issues from employee turnover begin with physical and mental health issues. Breuer (2015) stated suicide rates increase in developed countries when unemployment rates rise, which also costs society productive employees and money to support surviving family members. Drydakis (2015) conducted a longitudinal study in Greece where he concluded that physical and mental health declines in societies where unemployment rates increase. 
JEFAS

25,49

\section{4}

Figure 7.

Normal Q-Q plot of turnover intent

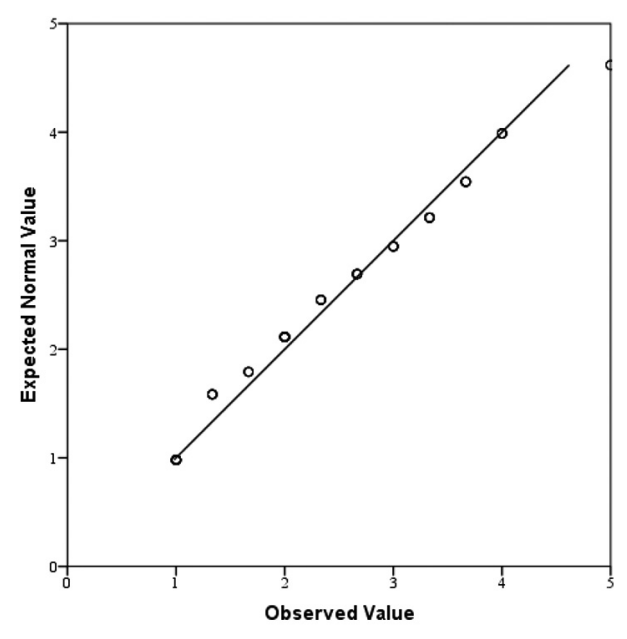

Source: Own elaboration

There are other societal benefits to managers working to reduce turnover besides better physical and mental health. Scholars noted that improved employee retention increases organizations' profits and could positively affect companies' abilities to increase philanthropic donations to the surrounding community (Chalmeta and Viinikka, 2017). Additionally, Chalmeta and Viinikka (2017) noted that companies who regularly participate in philanthropic donations in the community are more likely to have loyal and engaged employees, stronger productivity levels and stronger corporate social responsibility in general. Therefore, based on various scholars' research, it remains important that manufacturing managers in the Southeast understand the correlation between job satisfaction, job embeddedness, and turnover intent not only for the financial benefit to their company but also for the community in which the organization resides and the economy.

\section{Theoretical implications and study limitations}

Several limitations existed in this study, including the lack of generalizability, the selfreporting status of the participants and the correlational design. By using SurveyMonkey ${ }^{\circledR}$ Audience, the intent was to reach unbiased and generalized results among the manufacturing employees in the Southeastern USA. Bootstrapping occurred using SPSS, which helped validate the accuracy of the results. While generalization across all industries and global regions did not occur, generalization within the region and industry of focus occurred because of the platform used.

\section{References}

Ali, W. (2016), "Understanding the concept of job satisfaction, measurements, theories and its significance in the recent organizational environment: a theoretical framework", Archives of Business Research, Vol. 4 No. 1, pp. 100-111, doi: 10.14738/abr.41.1735.

Anaza, N. (2015), "Relations of fit and organizational identification to employee-customer identification", Journal of Managerial Psychology, Vol. 30 No. 8, pp. 925-939, doi: 10.1108/jmp-12-2012-0389. 
Andrews, F. and Withey, S. (1976), Social Indicators of Well-Being: American's Perceptions of Life Quality, Plenum Press, New York, NY.

Belias, D. and Koustelios, A. (2014), "Organizational culture and job satisfaction: a review", International Review of Management and Marketing, Vol. 4 No. 2, pp. 132-149, available at: www.econjournals.com/index.php/irmm

Bonett, D.G. and Wright, T.A. (2014), "Cronbach's alpha reliability: interval estimation, hypothesis testing, and sample size planning", Journal of Organizational Behavior, Vol. 36 No. 1, pp. 3-15, doi: 10.1002/job.1960.

Breuer, C. (2015), "Unemployment and suicide mortality: evidence from regional panel data in Europe", Health Economics, Vol. 24 No. 8, pp. 936-950, doi: 10.1002/hec.3073.

Chalmeta, R. and Viinikka, H. (2017), "Corporate philanthropy communication on donor websites", Journal of Information, Communication and Ethics in Society, Vol. 15 No. 1, pp. 53-73, doi: 10.1108/JICES-03-2016-0008.

Charlier, S., Guay, R. and Zimmerman, R. (2016), "Plugged in or disconnected? A model of the effects of technological factors on employee job embeddedness", Human Resource Management, Vol. 55 No. 1, pp. 109-126, doi: 10.1002/hrm.21716/pdf.

Chen, C. and Wen, P. (2016), "The effect of mentoring on protégés' organizational deviance", Psychological Reports, Vol. 119 No. 1, pp. 200-220, doi: 10.1177/0033294116659456.

Chen, Y., Li, Y., Wu, H. and Liang, L. (2014), "Data envelopment analysis with missing data: a multiple linear regression analysis approach", International Journal of Information Technology and Decision Making, Vol. 13 No. 1, pp. 137-153, doi: 10.1142/S0219622014500060.

Chhabra, B. (2015), "Person-job fit: mediating role of job satisfaction and organizational commitment", Indian Journal of Industrial Relations, Vol. 50 No. 4, pp. 638-652, available at: www.jstor.org/ journal/indijindurela

Choi, J.S. and Kim, K.M. (2015), "Job embeddedness factors as a predictor of turnover intention among infection control nurses in Korea", American Journal of Infection Control, Vol. 43 No. 11, pp. 1213-1217, doi: 10.1016/j.ajic.2015.06.017.

Crossley, C.D., Bennett, R.J., Jex, S.M. and Burnfield, J.L. (2007), "Development of a global measurement of job embeddedness and integration into a traditional model of voluntary turnover", Journal of Applied Psychology, Vol. 92 No. 4, pp. 1031-1042, doi: 10.1037/0021-9010.92.4.1031.

De Beer, L.T., Tims, M. and Bakker, A.B. (2016), "Job crafting and its impact on work engagement and job satisfaction in mining and manufacturing", South African Journal of Economic and Management Sciences, Vol. 19 No. 3, pp. 400-412, doi: 10.17159/2222-3436/2016/v19n3a7.

Denton, P.D. and Maatgi, M.K. (2016), "The development of a work environment framework for ISO 9000 standard success", International Journal of Quality and Reliability Management, Vol. 33 No. 2, pp. 231-245, doi: 10.1108/IJQRM-12-2013-0196.

Derby-Davis, M.J. (2014), "Predictors of nursing faculty's job satisfaction and intent to stay in academe", Journal of Professional Nursing, Vol. 30 No. 1, pp. 19-25, doi: 10.1016/j. profnurs.2013.04.001.

Drydakis, N. (2015), "The effect of unemployment on self-reported health and mental health in Greece from 2008 to 2013: a longitudinal study before and during the financial crisis", Social Science and Medicine, Vol. 128, pp. 43-51, doi: 10.1016/j.socscimed.2014.12.025.

Field, A. (2013), Discovering Statistics Using IBM SPSS Statistics, Sage Publications, Thousand Oaks, CA.

Findik, M., Ogut, A. and Cagliyan, V. (2013), "An evaluation about person-organization fit, job satisfaction, and turnover intention: a case of health institution", Mediterranean Journal of Social Sciences, Vol. 4 No. 11, pp. 434-440, doi: 10.5901/mjss.2013.v4n11p434.

Hancock, J.I., Bosco, F.A., McDaniel, K.R. and Pierce, C.A. (2013), "Meta-analytic review of employee turnover as a predictor of firm performance", Journal of Management, Vol. 39 No. 3, pp. 573-603, doi: $10.1177 / 0149206311424943$. 
JEFAS 25,49

Hauff, S., Richter, N.F. and Tressin, T. (2015), "Situational job characteristics and job satisfaction: the moderating role of national culture”, International Business Review, Vol. 24 No. 4, pp. 710-723, doi: 10.1016/j.ibusrev.2015.01.003.

Hayward, D., Bungay, V., Wolff, A.C. and MacDonald, V. (2016), "A qualitative study of experienced nurses' voluntary turnover: learning from their perspectives", Journal of Clinical Nursing, Vol. 25 Nos 9/10, pp. 1336-1345, doi: 10.1111/jocn.13210.

Herzberg, F., Mauser, B. and Snyderman, B. (1959), The Motivation to Work, Transaction Publishers, New Brunswick, NJ.

Huang, W. and Su, C. (2016), "The mediating role of job satisfaction in the relationship between job training satisfaction and turnover intentions", Industrial and Commercial Training, Vol. 48 No. 1, pp. 42-52, doi: 10.1108/ICT-04-2015-0029.

Hurt, A.A., Grist, C.L., Malesky, L.A. Jr. and McCord, D.M. (2013), "Personality traits associated with occupational "burnout' in ABA therapists", Journal of Applied Research in Intellectual Disabilities, Vol. 26 No. 4, pp. 299-308, doi: 10.1111/jar.12043.

Kanten, P., Kanten, S. and Gurlek, M. (2015), "The effects of organizational structures and learning organization on job embeddedness and individual adaptive performance", Procedia: Economics and Finance, Vol. 23, pp. 1358-1366, doi: 10.1016/S2212-5671(15)00523-7.

Karatepe, O.M. (2016), "Does job embeddedness mediate the effects of co-worker and family support on creative performance? An empirical study in the hotel industry", Journal of Human Resources in Hospitality and Tourism, Vol. 15 No. 2, pp. 119-132, doi: 10.1080/15332845.2016.1084852.

Ko, H.J. and Kim, J. (2016), "Relationships among nursing work environment, job embeddedness, and turnover intention in nurses", Journal of Korean Academy of Nursing Administration, Vol. 22 No. 3, pp. 279-291, doi: 10.11111/jkana.2016.22.3.279.

Lancsar, E. and Swait, J. (2014), "Reconceptualising the external validity of discrete choice experiments", PharmacoEconomics, Vol. 32 No. 10, pp. 951-965, doi: 10.1007/s40273-014-0181-7.

Lonial, S.C. and Carter, R.E. (2015), "The impact of organizational orientations on medium and small firm performance: a resource-based perspective", Journal of Small Business Management, Vol. 53 No. 1, pp. 94-113, doi: 10.1111/jsbm.12054.

Lu, A.C. and Gursoy, D. (2016), "Impact of job burnout on satisfaction and turnover intention: do generational differences matter?", Journal of Hospitality and Tourism Research, Vol. 40 No. 2, pp. 210-235, doi: 10.1177/1096348013495696.

Lyons, S. and Kuron, L. (2014), "Generational differences in the workplace: a review of the evidence and directions for future research”, Journal of Organizational Behavior, Vol. 35 No. S1, pp. S139-S157, doi: 10.1002/job.1913.

Marasi, S., Cox, S.S. and Bennett, R.J. (2016), “Job embeddedness: is it always a good thing”, Journal of Managerial Psychology, Vol. 31 No. 1, pp. 141-153, doi: 10.1108/JMP-05-2013-0150.

Meyers, L.S., Gamst, G. and Guarino, A.J. (2013), Applied Multivariate Research: design and Interpretation, Sage Publications, Los Angeles, CA.

Mitchell, T.R., Holtom, B.C., Lee, T.W., Sablynski, C.J. and Erez, M. (2001), "Why people stay: using job embeddedness to predict voluntary turnover", Academy of Management Journal, Vol. 44 No. 6, pp. 1102-1121, doi: 10.2307/3069391.

Mobley, W.H., Horner, S.O. and Hollingsworth, A.T. (1978), "An evaluation of precursors of hospital employee turnover”, Joumal of Apphied Psychology, Vol. 63 No. 4, pp. 408-414, doi: 10.1037/0021-9010.63.4.408.

Nicholas, A., Mensah, A.O. and Owusu, N.O. (2016), "Stay or leave? Using job embeddedness to explain turn over intention among hotel staff in Ghana", Journal of Management Research, Vol. 8 No. 3, pp. 123-139, available at: www.macrothink.org/journal/index.php/jmr

O'Keefe, A.P., Corry, M. and Moser, D.K. (2015), "Measuring job satisfaction of advanced nurse practitioners and advanced midwife practitioners in the republic of Ireland: a survey", Journal of Nursing Management, Vol. 23 No. 1, pp. 107-117, doi: 10.1111/jonm.12096. 
Pan, F.C. (2015), "Practical application of importance-performance analysis in determining critical job satisfaction factors of a tourist hotel", Tourism Management, Vol. 46, pp. 84-91, doi: 10.1016/j. tourman.2014.06.004.

Rani, N. and Samuel, A. (2016), "A study on generational differences in work values and personorganization fit and its effect on turnover intention of generation Y in India”, Management Research Review, Vol. 39 No. 12, pp. 1695-1719, doi: 10.1108/MRR-10-2015-0249.

Salman, M., Abdullah, F. and Saleem, A. (2016), "Sexual harassment at workplace and its impact on employee turnover intentions", Business and Economic Review, Vol. 8 No. 1, pp. 87-102, available at: http://imsciences.edu.pk/

Schmitt, A., Hartog, D. and Belschak, D.N. (2015), "Is outcome responsibility at work emotionally exhausting? Investigating employee proactivity as a moderator", Journal of Occupational Health Psychology, Vol. 20 No. 4, pp. 491-500, doi: 10.1037/a0039011.

Scott, R.E. (2015), "The manufacturing footprint and the importance of US manufacturing jobs", Economic Policy Institute Briefing Paper No. 388, available at: www.epi.org/publication/themanufacturing-footprint-and-the-importance-of-u-s-manufacturing-jobs/

Umamaheswari, S. and Krishnan, J. (2015), "Retention factors and their relative significance in ceramic manufacturing industries in India”, Asian Social Science, Vol. 11 No. 3, pp. 260-268, doi: 10.5539/ ass.v11n13p260.

Umans, T., Broberg, P., Schmidt, M., Nilsson, S. and Olsson, E. (2016), "Feeling well by being together: study of Swedish auditors", Work, Vol. 54 No. 1, pp. 79-86, doi: 10.3233/wor-162270.

United States Environmental Protection Agency (2016), "About EPA 4 (southeast)”, available at: www. epa.gov/aboutepa/about-epa-region-4-southeast

Upadhayay, L. and Vrat, P. (2016), "An ANP based selective assembly approach incorporating Taguchi's quality loss function to improve quality of placement in technical institutions", The TQM Journal, Vol. 28 No. 1, pp. 112-131, doi: 10.1108/TQM-06-2014-0054.

Vasquez, D. (2014), "Employee retention for economic stabilization: a qualitative phenomenological study in the hospitality sector", International Journal of Management, Economics and Social Sciences, Vol. 3 No. 1, pp. 1-17, available at: www.ijmess.com/

Wong, Y., Wong, Y. and Wong, C. (2015), "An integrative model of turnover intention: antecedents and their effects on employee performance in Chinese joint ventures", Journal of Chinese Human Resources Management, Vol. 6 No. 1, pp. 71-90, doi: 10.1108/JCHRM-06-2014-0015.

Word, J. and Park, S.M. (2015), "The new public service? Empirical research on job choice motivation in the nonprofit sector", Personnel Review, Vol. 44 No. 1, pp. 91-118, doi: 10.1108/pr-07-2012-0120.

Yu, M. and Kang, K.J. (2016), "Factors affecting turnover intention for new graduate nurses in three transitional periods for job and work environment satisfaction", The Journal of Continuing Education in Nursing, Vol. 47 No. 3, pp. 120-131, doi: 10.3928/00220124-20160218-08.

\section{Corresponding author}

Rocky J. Dwyer can be contacted at: rocky.dwyer@mail.waldenu.edu

For instructions on how to order reprints of this article, please visit our website: 